\title{
The political economy of state patronage of religion: Evidence from Thailand
}

\section{Tomas Larsson}

University of Cambridge, UK

Forthcoming in International Political Science Review

\begin{abstract}
Deciding the character and level of official patronage of religion are fundamental questions for all states. Yet we know next to nothing about the determinants of such patronage. Are democratic governments more or less inclined than autocratic ones to seek legitimacy through religious patronage? Is it ultimately ideological struggles that determine the extent of government backing of religion? This article addresses these questions through an analysis of the evolution of the state's role as patron and protector of Buddhism (and other officially recognised religions) in Thailand. Specifically, it examines changes in government expenditure on Thailand's religious bureaucracy from 1960 to 2016. It finds that democratization and ideological struggles have been the main drivers of a significant expansion of government spending on religious patronage.
\end{abstract}

\section{Keywords}

Religious legitimation; democratization; Buddhism; Thailand

\section{Corresponding author:}

Tomas Larsson, St John's College, Cambridge CB2 1TP, UK.

Email: th133@cam.ac.uk 
The challenges rulers face in managing religion in ways that support their political projects has in many polities resulted in the creation of state agencies dedicated to the support and control of religious organizations. In 2008, more than 54 percent of countries around the world had such religious bureaucracies. ${ }^{1}$ Yet, there is marked variation, across time and space, both in the purposes for and degree to which such agencies, alongside other arms of the state, intervene in religious affairs, and with what effects. Some of this variation is reflected in existing studies of state-religion arrangements (Sezgin and Künkler, 2014). Quantitative cross-national studies have shed important light on the character of state involvement in religion across the world. They have found that democracies tend to have a greater degree of separation between religion and state than autocracies, and that economically more advanced societies tend to adopt more secularist approaches toward religious affairs (Fox, 2006). However, these and similar studies have generally, and for understandable reasons, focused on laws and policies that speak to the degree of state involvement in religious affairs. Rarely do existing studies pay closer attention to the religious state apparatus as such. For example, popular indexes measuring the extent of government regulation and favouritism of religion merely record whether states have religious affairs ministries or departments (Fox, 2015), or whether states provide various kinds of funding for the religious sector (Grim and Finke, 2006). This contribution extends these lines of inquiry by leveraging the fact that a government's desire to control or support religion will manifest not only in the presence or absence of religious bureaucracies and different types of religious subsidies, but also in shifting levels of government spending. Specifically, it uses process tracing to identify the determinants of government expenditure on the religious bureaucracy.

Where they exist, religious bureaucracies can be more or less well funded, and government expenditure on such agencies therefore constitutes a central dimension of the comparative politics of religion. Indeed, "the nature of state patronage of religion is a fundamental issue for any polity" (Chaves et al, 1994: 1088). There are two advantages of making use of budget data. First, whereas existing studies on state-religion relations reduce state funding of religion to dichotomous variables (states either provide certain kinds of religious patronage or they don't), this contribution seeks to exploit the fact that government expenditure is a continuous variable. Second, budget data allows us to explore the political economy of state intervention in religious affairs beyond the brief periods covered by quantitative indexes designed to measure the character of government regulation and support of religion. ${ }^{2}$ That said, budgets for religious 
bureaucracies are not a perfect measure of state patronage of religion. Governments may provide support to religious organizations through nominally secular parts of the state bureaucracy (as is the case in Russia, where the state cooperates closely with Russian Orthodox Church in a variety of fields; and in the United Kingdom, where the state funds religious, including Islamic, schools), or by raising Church taxes on behalf of officially recognized religious organizations (as is the case in Germany). They may also support religion indirectly, by, for instance, making charitable donations to religious organizations tax deductible and religious organizations tax exempt (as is the case in many countries that do not have religious bureaucracies, such as the United States) (see Stepan, 2011). While fully recognizing that religious patronage may take a variety of forms, the premise of this article is that in countries with religious bureaucracies, budget allocation to the religious bureaucracy is one important indicator of the effort made by the state to support and control religious life. However, it is a more reliable indicator of trends in state patronage of religion than of absolute levels.

Why should we care about government expenditure on religion? In many countries, including Thailand, the religious bureaucracy accounts for but a minuscule part of the overall government budget. Unlike their pre-modern predecessors, contemporary rulers rarely break the bank in their efforts to acquire religious legitimacy. However, the political importance of official religious patronage tends to exceed its fiscal significance. As one central dimension of religion-state relations and as a means of political legitimation, state patronage of religion is likely to impact the dynamics of political development, including processes of state formation, nation building, and democratization. Furthermore, the very existence of a religious bureaucracy raises obvious normative concerns about religious liberties and oppression of religious minorities. However, it is certainly possible for states to heavily favour one religion without necessarily regulating religious life in a very coercive manner, and Thailand is arguably an example of this (Driessen, 2014: 233). But state patronage of religion can have serious (unintended) consequences also under comparatively benign circumstances. For instance, state support of religion appears to sap religious civil society of its vitality (Chaves et al, 1994; Traunmüller and Freitag, 2011). McCargo (2012) has noted the deleterious effect of the Thai state's tight embrace of the Buddhist monastic order. He has also highlighted how its efforts to co-opt Islamic leaders by channeling significant financial resources in support of Islamic education paved the way for the rise of a violent separatist insurgency by alienating the Malay-Muslim grassroots from their traditional 
religious authority figures (McCargo 2008). If state patronage of religion matters for things political scientists care about, then it is also incumbent on us to get a better understanding of its driving forces.

The article is divided into five main parts. I first review the literature on the comparative politics of religion to develop an analytical framework. I then provide a brief introduction to Thailand's religious bureaucracy. Next, I explore evidence on government budget allocation to the religious bureaucracy from 1960 to 2016. I then discuss the political and religious context in which major shifts in state financing of religion have taken place. I argue that democratization and ideological struggles have been key drivers of increased state expenditure on religion. I conclude by highlighting opportunities for future research.

\section{Analytical Framework: The Political Economy of Religious Patronage}

The political economy of official religious patronage is not well understood. The existing literature provides few answers to the question of what drives state patronage of religion. Given

the limits to our existing knowledge, studies focused on a single country's experience can make a significant contribution to theory development by identifying variables and mechanisms that may explain variation in government patronage of religion. Even so, the broader literature on the comparative politics of religion can serve as a source of initial ideas about factors possibly determining outcomes. I draw on it to generate intuitions about how changes in political institutions and ideological struggles might affect states' religious proclivities.

While there are many dimensions on which political institutions vary, the scope of this inquiry will be limited to one: regime type. The notion that democracies and autocracies have different political priorities that are reflected in decisions relating to public expenditure is not a novel one. Democracies are, for example, known to spend more on education and healthcare than autocracies. While the rational choice approach to understanding the politics of religion has highlighted the level of political competition as a key factor in determining the character of statereligion relations (Gill, 2007), it has been conspicuously silent on the question of how regime type might affect incentives for governments to adopt a friendly attitude towards religion. The rational choice approach nevertheless provides a useful starting point for thinking through the implications of regime change for the political cost/benefit calculations associated with efforts to 
gain religious legitimacy. It assumes that political actors above all are interested in securing their own political survival, and that decisions by governments to allocate financial resources to religion (rather than, say, arms, education, or public health) will be driven by straightforward calculations of political opportunity costs. In effect, the degree to which scarce resources are devoted to religious patronage will reflect the degree to which religious organizations can make or break the careers of political leaders.

Under what circumstances, then, are religious leaders best positioned to do this? Arguably, governments face greater risks that prominent religious actors will be able to tip the political scales in situations of intense political competition (Gill, 2007). We can posit that the level of political competition is likely to be higher in democracies than in autocracies, given that the nominal selectorate (i.e., all people who have a say in choosing government leaders) tends to be significantly larger in democracies than in autocracies (Bueno de Mesquita et al, 2003). Likewise, we may assume that competition will be higher in authoritarian regimes with flawed but meaningful elections than in those without (Levitsky and Way, 2010). Indeed, in Malaysia, a paragon of precisely such "competitive authoritarianism," electoral rivalry has been identified as a key driver of the runaway growth of that country's Islamic bureaucracy (Mohamad 2010). We thus have good reasons to think that democratization and the introduction of competitive elections will unleash dynamics where religious patronage becomes increasingly salient as an instrument of political legitimation. Recognizing this possibility, Driessen (2014: 15) recently proposed "religiously friendly democratization" as a distinct path of political development, in which political elites adopt "very friendly" policies toward religious actors and institutions to "generate important sources of stability for a young, fragile democratic regime."

From a methodological perspective, Thailand is a particularly useful case in which to study the effects of political institutions, for two reasons. First, because the kingdom has provided something of a natural experiment in the form of multiple episodes of democratization and dedemocratization. Second, because regime change in Thailand has not coincided with any paradigmatic changes of religion-state relations. In many other countries, the latter condition may not hold. In such cases, it may well be that an analysis of changes in the political economy of state patronage of religion must place greater weight on more fundamental reconfigurations of religion-state relations. Furthermore, the effect of regime change on state patronage of religion is likely to be profoundly affected by the degree to which powerful religious organizations are 
"institutionally linked (or credibly committed)" to any particular political faction (Gill, 2007: 54). The impact of regime change may thus be contingent on the nature of the links between dominant religious organizations and the previous regime. This is one important background condition that shapes the political logic of religious patronage. Regime change may have different implications depending on the nature of the historical baseline. Democratic windfalls should not be expected where the religious establishment has positioned itself as a staunch defender of the ancien régime (Kuru, 2007). Conversely, autocratic windfalls might be expected where a dominant religious organization has committed itself to a ruling faction in order to jointly re-sacralize a previously highly secularized political order (e.g., the Russian Orthodox Church in Vladimir Putin's Russia). In the case of Thailand, the Sangha is institutionally linked and credibly committed to the monarchy and to the state as such, but not to the various political factions - military and civilian - that have won and lost power over the past few decades. ${ }^{4}$

As this suggests, political institutions are not the only possible determinants of the degree to which religious actors can pose a threat to regimes. Variation in state patronage of religion could also mirror the rise and fall of factions with distinct ideological perspectives on the position and role of religion within the polity. Kuru (2007) has shown how nominally secular states pursue different policies towards religion because of such ideological struggles. One might thus expect variation in state patronage of religion to reflect shifts in the political fortunes of secularists and religious political movements of different stripes. In recent decades, such struggles have intensified in many parts of the world, including Asia, as a result of the rise of religious political movements, often with close links to political parties, who demand that the secular state allocate resources to support and protect the (perceived) religious "core" of national identity (Kinnvall, 2004).

Before proceeding, an alternative explanation for changes in the level of state patronage of religion needs to be addressed: socio-economic development. In the period under study, the Thai economy has been fundamentally transformed, and it is not unreasonable to think that economic and social modernization might impact the political economy of state patronage of religion. One particularly salient line of argument views economic development — and economic globalization in particular - as a factor that, contrary to the predictions of secularization theory (Inglehart and Norris, 2011), may be expected to increase demands for state patronage of religion. Kinnvall (2004), for example, explains the rise of religious nationalist movements in the 1990s as a social 
and political response to the "ontological insecurity" induced by economic globalization. However, socio-economic transformations do not impact official religious patronage directly their effects are mediated by political institutions and ideological struggles, along the lines discussed above.

In the following, I will argue that changes in political institutions has had a significant impact on state patronage of religion in Thailand. Specifically, democratization has frequently resulted in significant windfalls for the religious bureaucracy. Conversely, the advent of military rule has frequently been followed by sharp falls in religious spending. This suggests that electoral competition provides a strong incentive for political leaders to seek religious legitimacy. I will also argue that, although the overarching ideological framework within which all governments in the period under study have operated has remained constant, Thai political debates since the 1990s reflect a growing perception of threat against Buddhism. Thai political elites have therefore had to contend with increasing public pressures to "do something" to protect Buddhism. One of the things they have done is to boost state patronage of religion by significantly increasing the budget for the religious bureaucracy.

\section{Thailand's Religious Bureaucracy}

The religious bureaucracy that we find in Thailand today is a legacy from pre-modern processes of state formation. As classic works of Southeast Asian politics have emphasized, the early states of the region were conceived of as serving cosmological purposes informed by Hindu and Buddhist worldviews, and this was central to their legitimation. In the $19^{\text {th }}$ and early $20^{\text {th }}$ Centuries, modernizing monarchs effectively fused the modern Thai state and nation with particular conceptions of Buddhism (Jackson, 1989; Keyes, 1989).

In the period under study here, all government expenditure on the religious bureaucracy had a single recipient - the Department of Religious Affairs in the Ministry of Education — until 1997. That year, the two Buddhist universities that had originally been established by King Chulalongkorn-Mahachulalongkornrajavidyalaya University (MCU) and Mahamakut Buddhist University (MBU) — were transferred from the DRA to the Ministry of University Affairs. In October 2002, the bulk of the activities of the DRA were transferred to the National Office of Buddhism (NOB). DRA was simultaneously transferred to the Ministry of Culture, where it is 
now mainly responsible for overseeing officially recognized minority religions (Islam, Christianity, Hinduism, and Sikhism). Taken together, the NOB and the two Buddhist universities today represent the specifically Buddhist state bureaucracy - and together they account for the lion's share of the budget allocated to the religious bureaucracy (see Figure 1). ${ }^{5}$

Despite this recent history of bureaucratic reshuffling, the main administrative functions of the religious bureaucracy have remained intact. The DRA served as the secretariat for the Sangha Supreme Council (SSC); paid monthly stipends to Sangha ecclesiastics with administrative duties; managed temple properties; promoted and regulated religious education; sponsored and regulated Buddhist missionary activities; and supported the construction and maintenance of temples. It also played a key role in planning and arranging royal and royally sponsored Buddhist rituals, notably the annual kathin ceremonies that are the hallmark of a righteous Buddhist ruler (Gray, 1986). Most of these functions were transferred to the NOB. While much has changed since the pre-modern era, the Thai state is still conceived of as serving a soteriological purpose.

Figure 1. Government budget appropriation for the religious bureaucracy, by recipient, fiscal years 1960-2016.

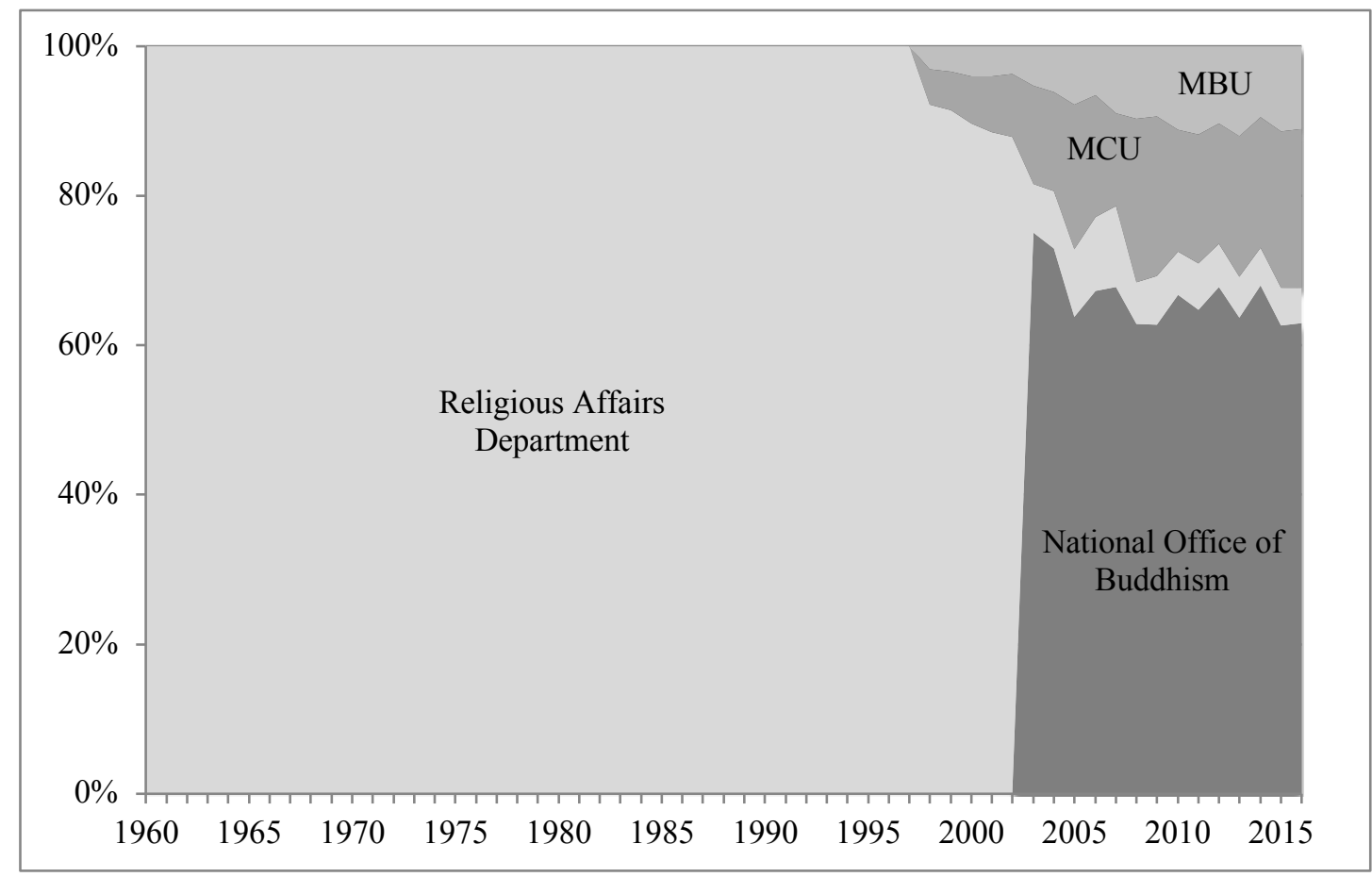




\section{Budgets for Buddhism, 1960-2016}

In recent decades, Thai governments have significantly increased their spending on the religious bureaucracy. In relative terms, expenditure on Thailand's religious bureaucracy rose from a historic low of 0.08 percent of the national budget for the 1989 fiscal year to a historic high of 0.32 percent in the budget for the 2008 fiscal year-an increase of 300 percent (see Figure 2). ${ }^{6}$ The chart also reveals that exceptionally high levels of growth characterize several distinct periods. Particularly striking are the twin spikes in the 1970s, and the rapid increase in the early 1990s.

Figure 2. Budget appropriation for the religious bureaucracy as share of the national budget, fiscal years 1960-2016.

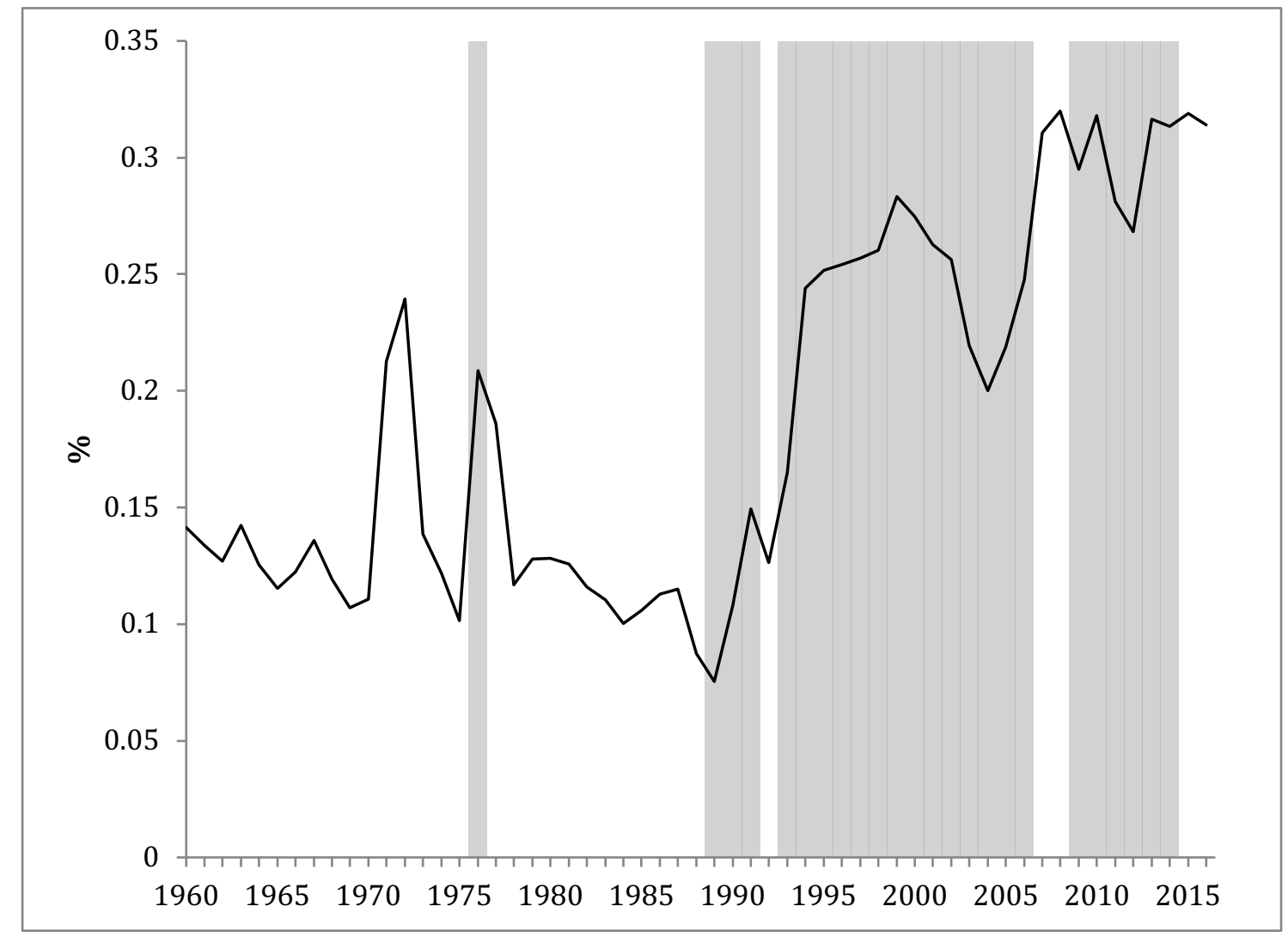

Note: Shaded bands indicate budgets passed by democratic governments. Source: Geddes et al (2014) for 1960-2010; author's coding for the remaining years. 
What, then, might explain these patterns?

\section{The Political Economy of Religious Patronage in Thailand}

\section{Political institutions}

As a first move to address the question whether changes in political institutions may have affected the level of government support for the religious bureaucracy the shaded bands in Figure 2 indicate budgets passed by democratic governments. ${ }^{7}$ It is apparent that the advent of democratic forms of government in 1975, 1988, and 1992 were followed by exceptional increases in the fiscal resources showered on the religious bureaucracy in subsequent budgets. However, it is also apparent that the religious bureaucracy reaped windfalls under some autocratic governments, as is the case in fiscal years 1971 and 1972 and, to a lesser extent, in fiscal year 2007. The first half of the 1990s also stands out as a critical juncture, during which expenditure on the religious bureaucracy is ratcheted up, and following which volatility is much reduced and the positive co-variation between regime change and religious-patronage effort appears to break down. Unlike earlier instances, the autocratic reversals in 2006 and 2014 do not bring about sharp falls in the (relative) level of expenditure on the religious bureaucracy. In the period under study, the median share of the national budget allocated to the religious bureaucracy was 0.26 percent for democratic regimes, and half as much, 0.13 percent, for autocratic regimes. Thus, Thai governments have differed greatly in the relative political weight put on the religious bureaucracy — and hence on religious legitimation - and at least for some periods this variation correlates with changes in political institutions.

To bring out the regime-related dynamics even more clearly, Table 1 presents the track records of Thai prime ministers in terms of their official patronage of religion. It shows the average annual rate at which the share of the national budget going to the religious bureaucracy grew (or shrank) during their tenure in office. The table also indicates the type of regime the different prime ministers represented. Strikingly, three elected prime ministers-Kukrit Pramoj, Chatichai Choonhavan, and Chuan Leekpai (I) — stand out as having treated the religious bureaucracy most lavishly. In contrast, unelected prime ministers have been by far the least charitable. This provides further evidence that regime type has affected the extent to which Thai 
governments devote scarce resources towards religious legitimation. Furthermore, it was under the first three democratic prime ministers that religious patronage experienced particularly rapid increases. Religious patronage therefore appears to be is an especially salient legitimation strategy in the early stages of democratization. ${ }^{8}$

Table 1. Thailand's prime ministers and the relative budgetary gains of the religious bureaucracy, fiscal years 1960 to 2016.

\begin{tabular}{|c|c|c|c|}
\hline Prime minister & $\begin{array}{l}\text { Budget } \\
\text { years }\end{array}$ & $\begin{array}{l}\text { Democratic } \\
\text { regime* }\end{array}$ & $\begin{array}{l}\text { Change in share of total budget } \\
\text { allocated to the religious bureaucracy, } \\
\text { annual average growth rate }(\%)\end{array}$ \\
\hline Sarit Thanarat & $1960-1963$ & No & 0.51 \\
\hline Thanom Kittikachon & 1964-1974 & No & 2.62 \\
\hline Sanya Dharmasakti & 1975 & No & -16.62 \\
\hline Kukrit Pramoj & 1976 & Yes & 105.29 \\
\hline Sangad Chaloyu ${ }^{* *}$ & 1977 & No & -10.94 \\
\hline Thanin Kraivichien & 1978 & No & -37.15 \\
\hline Kriangsak Chamanan & $1979-1980$ & No & 4.93 \\
\hline Prem Tinsulanonda & 1981-1988 & No & -4.23 \\
\hline Chatichai Choonhavan & 1989-1991 & Yes & 22.65 \\
\hline Anand Panyarachun & 1992 & No & -15.28 \\
\hline Chuan Leekpai (I) & 1993-1995 & Yes & 27.15 \\
\hline Banharn Silpa-archa & 1996-1997 & Yes & 1.01 \\
\hline Chavalit Yongchaiyudh & 1998 & Yes & 1.39 \\
\hline Chuan Leekpai (II) & 1999-2001 & Yes & 0.46 \\
\hline Thaksin Shinawatra & $2002-2006$ & Yes & -0.61 \\
\hline Surayud Chulanont & $2007-2008$ & No & 14.17 \\
\hline Somchai Wongsawat & 2009 & Yes & -7.79 \\
\hline Abhisit Vejjajiva & $2010-2011$ & Yes & -1.89 \\
\hline Yingluck Shinawatra & $2012-2014$ & Yes & 4.12 \\
\hline Prayuth Chan-ocha & $2015-2016$ & No & 0.15 \\
\hline
\end{tabular}

Notes: *Source: Geddes et al (2014) for 1960-2010; author's coding for the remaining years. ** Sangad Chaloyu was never prime minister; he ruled the country as chairman of a military junta.

These are intriguing patterns, which indicate that the advent of democracy is associated with increased government spending on the religious bureaucracy. But what are the mechanisms producing such increases? The literature on elections in Thailand suggests that the sharp rise in effort to gain religious legitimacy under democratic regimes may be driven by the social and cultural pressures that politicians face when trying to win voter support. This reflects a moral economy of Buddhist merit making, in which the powerful are expected to contribute to the 
welfare of the community, not least by making conspicuous donations to Buddhist temples. Operating in such a cultural environment, political parties and parliamentarians realised that patronage of Buddhism was key to successful electioneering, especially in rural areas where the majority of voters are found (see Phillips 1958: 49; Somboon 1977: 17; Arghiros 1993: 187). According to former prime minister Chuan Leekpai, Thai parliamentarians face an electoral imperative to establish good relationships with monks in their constituency. "When I was electioneering ( $h$ a siang) I would go to the temple in every village to pay my respects to the monks (wai phra). Even if the monks are not allowed to vote, it would be helpful if they spoke well of me [to the villagers]. It's nothing strange. At that point, the monks might ask for budget to help repair the chapel (bot), the monks' cloisters (kuti), etc." ${ }^{\prime 9}$ Reflecting on the rapid increase in budget allocation for the religious bureaucracy under his premiership, Chuan Leekpai observed that he made it a priority to raise the government stipend (nitayapat) for ecclesiastical monks both times he became prime minister. He explained this, in part, with reference to his personal sense of gratitude towards Buddhism; as a young man he had spent several years as a temple boy (dek wat). But he also pointed to the pressures for increased government support for the monkhood that followed in the wake of broader social changes. ${ }^{10}$ Given that parliamentarians are evaluated by the electorate on basis of their ability to support Buddhism locally, it follows that they also have an incentive to use their powers as members of parliament to funnel part of the government budget towards religious patronage. ${ }^{11}$

Autocratic political leaders may of course also recognize the importance of acting as patrons of Buddhism to gain religious legitimacy. Pious Thai autocrats, like the absolute monarchs of the past, would, however, have an incentive to concentrate their religious patronage to the geographic and symbolic center of the polity-because they can. In comparison with a democratic parliament, autocrats do not need broad popular backing and they therefore have less to gain by extending their religious patronage to encompass village temples nationwide in any more systematic fashion. Autocratic regimes do of course require the backing or at a minimum the passive acceptance of communal elites at the national level—which in the Thai case means the monarch and the top Sangha hierarchs in Bangkok. Currying their favour has required ritual displays of loyalty and submission, in line with royalist conceptions of Thai nationalism, but not extravagant spending on the religious bureaucracy. Given the military's historical role as defenders of "nation, religion, king," Thai military autocrats have tended to regard the legitimacy 
of their - royally endorsed — rule with considerable confidence. Unlike parliamentarians, they therefore have not been compelled to "buy" the support of the wider monkhood to the same extent.

So far the discussion concerning the relationship between regime type and religious patronage has been based on a dichotomous conception of regime type (democracy/autochracy). While there are distinct advantages to this approach, it is too crude to be able to reflect all the ways in which differences in political institutions have impacted government patronage of religion in Thailand. There are important institutional differences also among the non-democratic regimes that have ruled Thailand over the past few decades. The most salient contrast is between nondemocratic regimes with an elected legislative assembly and those without. This raises the question: Does the introduction of an element of electoral competition within non-democratic regimes affect the political economy of religious patronage? There is some evidence to suggest that it does. Elections in non-democratic regimes can serve as a spur of official religious patronage, but it doesn't always do so. A comparison of two periods of "semi-democratic" rule will illuminate.

Thailand was an autocracy in the early 1970s and also for most of the 1980s. In both these periods Thailand experimented with a hybrid form of regime, in which a non-elected military strongman as head of government shared power with an elected legislature.

It is therefore striking that the brief spike in religious spending under Field Marshal Thanom Kittikachon (prime minister 1963-73) in the early 1970s coincided with the introduction of an elected legislative assembly. In February 1969, parliamentary elections had been held for the first time since 1957. This evolution of the military-dominated regime toward a more competitive form of authoritarianism had an almost immediate effect on government spending directed towards Buddhist temples. The budget for fiscal year 1970 funded restoration and development of 930 temples nationwide, representing close to a tripling of the previous year's level (fiscal year 1969: 315 temples) (Religious Affairs Department, 1970: 130-1). Increased political competition resulted in intensified politicization of religious patronage, and in efforts by parliamentarians to direct the government budget towards projects, such as support for Buddhist temples, that would help boost their public image in their constituencies. Newly elected members of the House of Representatives managed to wrestle some control of the budget process away from the prime minister and the technocrats in the Bureau of the Budget, enabling them to 
fashion a budget that reflected the expectations of their constituencies, primarily with regards to local economic and social development projects (Neher, 1971: 133; Mezey, 1973: 312), but also with regard to the patronage of religion. It was in the context of this parliamentary ascendancy that the budget for fiscal year 1971 disproportionately boosted government spending on the religious bureaucracy - increasing it by more than 100 percent in absolute terms, and almost as much in relative terms, compared to the budget for the previous year. Spending on the religious bureaucracy was disproportionally increased also in the budget for fiscal year 1972, albeit less dramatically so. Thanom put an end to the parliamentary experiment by staging a coup against his own government in November 1971. Parliament was abolished, and political parties banned. With full autocratic control restored, Thanom's last two budgets, for fiscal years 1973 and 1974, slashed spending on the religious bureaucracy, in both absolute and relative terms. This surge in spending following partial democratization, followed by a decline in the aftermath of autocratic reversal, provides a preview of what will happen once budget processes are re-democratized in 1975, 1988, and 1992.

The return to semi-democracy in the 1980s did not, however, lead to a similar surge in state patronage of religion. With the reintroduction of an electoral element into the governance mix under General Prem Tinsulanonda (prime minister 1980-88) one might expect that the political dynamic that had led to a rapid increase in spending on the religious bureaucracy under a similar semi-democratic arrangement in the early 1970s would have reasserted itself. It did not. Unlike Thanom, Prem and his team of economic technocrats retained tight control of all aspects of macroeconomic policymaking. Reflecting conditions under Prem in particular, Thailand's budget process was described as so "rigid" that it "effectively prevents elected representatives from developing programs or responding to voter demands through public spending" (Christensen et al, 1993: 27).

Thus, under semi-democratic conditions Thai parliamentarians have occasionally been able to use the national budget to respond to voters' religious expectations; under democratic conditions they have always been able to do so. The process of democratization therefore stands out as an important driver of official state patronage of religion in Thailand. It is, however, also clear that the impact of regime change declines over time. The patterns observed in the 1970s, 1980s, and 1990 s have not been repeated since the turn of the century. 


\section{Ideological Struggles}

Next we must ask whether it is possible that the patterns of religious patronage reflect the outcome of ideological struggles over the role of religion rather than changes in political institutions. The answer is not straightforward. The dramatic fluctuations that were observed in the 1970s and late 1980s cannot be explained by ideological factors. They are primarily the result of changes in political institutions. However, the ratcheting up of religious spending in the 1990s and the stabilization of such spending at a higher level does, at least in part, reflect intensified ideological struggles.

Historical experiences shape the ideological orientation of political actors, and, as a consequence, the character of religion-state relations under different types of political regimes. Where religious organizations have been intertwined with autocratic regimes, for instance, regime change often results in a secularist backlash against religion. Perhaps Thailand's military autocrats (like their colleagues in Turkey) have just been more secular in orientation than elected leaders who better reflect popular devotion to Buddhism? This seems implausible. Since the late 1950s, autocratic Thai governments have been committed to a hegemonic conception of "Thainess" in which Buddhism is one of the three pillars of national identity. The booms and busts of religious patronage in the 1970s and 1980s therefore cannot be said to reflect the vicissitudes of ideological struggles.

It is however possible that ideational and institutional factors interact in ways that reinforce the feast-and-famine pattern experienced by the religious bureaucracy in the 1970s and 1980s. Government patronage of religion arguably carries different symbolic connotations under conditions of personalized authoritarian rule than under conditions of decentralized and fragmented electoral competition. Through grandiose acts of religious patronage, authoritarian strongmen risk giving rise to the impression that they are entering into symbolic competition with Buddhism's primary patron and protector, according to royalist conceptions of Thai nationalism: the monarch. In fact, Phibun Songkhram's extravagant patronage of Buddhism in the 1950s was understood in terms of competition with the king (Thak, 2007: 66). Under democratic governments that risk is much reduced, as any credit for official religious patronage is diffused among all members of the governing coalition. 
What then of developments since the mid 1990s, after which it becomes much less clear whether changes in political institutions have much of an effect on levels of religious patronage? Recall in particular that the fall of democracy in 2006 and 2014 did not have the kind of serious negative effects on state patronage of Buddhism that typically accompanied autocratic reversals in the 1970s and (to a lesser extent) in 1992. Is it possible that ideological struggles have trumped political institutions?

There is some evidence to support such an argument. Ideological struggles over the position of Buddhism within the Thai polity have intensified since the late 1980s. But it has not been a conflict pitting religious nationalists versus secularists. Rather, different stripes of religious nationalists have been in broad agreement that Thai Buddhism is in "crisis" (Kusa, 2007). The sense of alarm was in part grounded in a perceived threat from new religious movements, such as Santi Asoke and Wat Phra Dhammakaya. It was in part caused by frank and irreverent mass media reports, made possible thanks to democratization, that exposed a long series of misbehaving monks (Gabaude, 1996: 247-253). Thus, Kukrit, the former prime minister, in 1990 penned a pamphlet entitled Crisis in Buddhism, where he highlighted how institutional Buddhism was failing to adapt to changing social and political conditions (Kusa, 2007: 43).

While there is disagreement about the precise nature of that crisis, and over appropriate institutional arrangements to address it, few have challenged the notion that the state has a central role to play in the provision of patronage and protection of religion. High levels of government spending on the religious bureaucracy has therefore enjoyed continuing appeal across political and sectarian divides.

Conservative groups perceived the new religious movements as "a distinct threat to Thai Buddhism and to the regulated and ordered symbols of civil power and authority" (Taylor, 1993: 79). This perception gave rise to demands for a strengthening of the religious bureaucracy. Indeed, it was claimed that underfunding of the RAD "had partly been responsible for the proliferation of illegal sects [such as Santi Asoke]" (Bangkok Post, 1989). Conservative Buddhist groups also argued that Santi Asoke's advances ought to be countered by making Buddhism the official national religion (Taylor, 1993: 74). At the same time, others perceived the "corruption" of the Sangha as the more fundamental threat to the integrity of the religious pillar of national identity. The political ascendancy in the early 1990s of Santi Asoke's most prominent lay supporter and the leader of the Palang Dhamma Party (PDP), Chamlong Srimuang, thus led to an 
intensification of official efforts to "strengthen" Buddhism. Much like the orthodox monks who had expelled Santi Asoke from the Sangha (from which it had declared independence), Chamlong viewed Buddhist morality as the solution par excellence to all of Thailand's political, economic, and social problems (McCargo, 1997). In light of this, it is perhaps not surprising that state expenditure on religion should have grown so dramatically from 1992 to 1995, when the PDP was the second-largest party in parliament and part of the governing coalition headed by Chuan Leekpai. Despite the ideological and sectarian rifts between conservatives and progressives that had opened in Thai politics, there was broad consensus that the state needed to do more to ensure the flourishing of Buddhism.

It is telling that democratic governments in the late 1980s and early 1990 s not only increased spending on the religious bureaucracy, they also shifted spending towards areas that suggest that they were responding to concerns about a crisis in institutional Buddhism and in public morality (Gabaude, 1996). Thus, the Chatichai government made massive investments to reform and strengthen the Sangha's administration, and to support religious education. The Chuan government, in turn, prioritized efforts to subject citizens to "moral education," to support religious education, and to strengthen the administrative capacity of the ecclesiastic hierarchy. To boost its institutional capacity to enforce proper behaviour of monks, the Sangha in 1993 established a monastic police force tasked with disciplining its own members (Kusa, 2007: chapter 5). DAR funded the resultant Police Monks' Operations Center. Thus, while templecentred pork-barrel politics remained an important dimension of government patronage of religion under the democratic governments of the late 1980s and early 1990s, resources were also shifted towards institution building.

The administrative and educational reforms prescribed by the 1997 constitution further heightened anxieties about the position of Buddhism within the Thai polity (Suwanna, 2003; Kusa, 2007; Katewadee, 2013). Indeed, in 2001, the SSC drafted and pushed for the enactment of a new Sangha Act, intended to secure Buddhism's "special" position within the Thai polity. After the SSC failed to get the draft through parliament, leading Sangha hierarchs backed the creation of a civil-society-styled Sangha proxy, named the Buddhism Protection Center of Thailand (BPCT), which was designed to advance the Sangha's political agenda in the public sphere. In September 2002, the BPCT rose to political prominence when it organized a concerted propaganda effort and led mass monastic protests. As a consequence, the government headed by 
Thaksin Shinawatra was forced to establish the ONB to ensure that the state bureaucracy would manage Buddhist affairs separately from those of other religions, thus signalling Buddhism's "special" position within the Thai polity (Kusa, 2007: chapter 3). In subsequent years the BPCT and other conservative civil society groups, often centred around the public Buddhist universities, have mobilised to secure firmer political commitments to state Buddhism, not least in hitherto unsuccessful attempts to make Buddhism official state religion in conjunction with the drafting of the constitutions enacted in 1997, 2007, and 2017. They have also pushed, so far unsuccessfully, for the enactment of a law for the patronage and protection of Buddhism. It would, if enacted in its draft form, establish a special government-run fund to shower even more money in support of official Thai Buddhism (Larsson, 2016: 24-25).

Since 2005, the Thai political system has experienced an unprecedented crisis of political legitimacy. The conflict between so called Yellow Shirts and Red Shirts (i.e., opponents and supporters, respectively, of Thaksin Shinawatra and his affiliates) has resulted in a cycle of mass protests, violence, coups (military and judicial), and elections. In this climate of increasing polarization, religious passions have been stoked. While the conflict cannot be reduced to religious factors, or neatly be mapped onto religious or sectarian identities, it has nevertheless become apparent that Buddhist groups have aligned themselves with ideological partisans. Thus, Santi Asoke and prominent representatives of the forest monk tradition abandoned Thaksin, whom they had originally supported, and joined the counter-majoritarian Yellow Shirts. The majoritarian Red Shirts, in contrast, found support within important parts of the Sangha hierarchy and from the BPCT. There was also a perception that Thaksin, after alienating his original religious backers, had formed a new alliance with Wat Phra Dhammakaya (see Katewadee, 2013).

The fact that government spending on the religious bureaucracy since 2005 has reached unprecedented levels must be understood in relation to continuing alarm over the state of Thai Buddhism and ideological mobilization of rival groups in "defence" of Buddhism. It is no surprise, in this transformed ideological context, that autocratic governments have found it expedient to maintain high levels of state patronage of religion after they have seized power from democratic governments. In some ways religion is today a more important factor of political legitimation than ever before, and this is reflected in budgets for the religious bureaucracy. 


\section{Conclusion}

This account of the political economy of religious patronage in Thailand provides evidence that political institutions and ideological struggles affect government spending on religious patronage. In Thailand, democratic governments have tended to allocate more funds towards religious purposes than their autocratic counterparts, and electoral competition stands out as one of the main drivers of religious patronage. This is mainly due to the fact that electoral competition creates incentives for politicians to meet not only the material but also the religious expectations of voters. This explains, at least in part, the dramatic increases in government spending on religious affairs that tend to ensue when parliamentarians take control of public spending decisions from autocratic governments (and their technocratic allies). While autocratic leaders are also expected to act as patrons of Buddhism, the pressures they face have generally been more limited, and they have therefore often been inclined to cut back on the budget for religious patronage after it has been ratchetted up by popularly elected predecessors.

Since the 1990s, however, it has become increasingly clear that the character and level of government patronage of religion reflects, in part, ideological struggles over the relationship between religion and state. The waning significance of political institutions as a determinant of religious patronage has become manifest in the wake of the 2006 and 2014 military coups. The sustained high levels of spending on the religious bureaucracy under democratic and autocratic governments alike reflect religious political mobilization that no government can easily ignore. Amidst heightened pereptions of a variety of increasingly potent "threats" to Buddhism, religious actors have successfully adopted street-based politics to compel governments to demonstrate greater commitment to the patronage and protection of what they perceive to be correct forms of the dominant religion. Governments have pandered to such sentiments through increasingly generous backing of Buddhism.

The effects of democratization and ideological struggles on state patronage of religion might fruitfully be explored also in other countries. Within Southeast Asia, the political drivers of state patronage of religion can be explored in Indonesia and Burma/Myanmar, which have both undergone significant political transitions in recent years. More ambitiously, the creation of datasets on budget allocations to religious bureaucracies by governments across the world would 
allow political scientists to shed new light on broader regional or global trends and patterns in official religious patronage.

\section{Acknowledgements}

I am grateful for helpful feedback when earlier drafts of this work were presented at Lund University, Singapore National University, SOAS, and the 2016 ASEASUK conference. I am indebted to the anonymous reviewers and editors of International Political Science Review for their constructive comments. Finally, I am thankful for research assistance by Peera Charoenvattananukul and Phurich Ariyarak.

\section{Funding}

This research received no specific grant from any funding agency in the public, commercial, or not-for-profit sectors.

\section{Notes}

${ }^{1}$ Data from

http://www.thearda.com/Archive/Files/Analysis/RAS2012/RAS2012_Var1966_1.asp. Accessed 11 December 2015.

2 The Religion and State Dataset, for instance, covers the period from 1990 to 2008. The indexes developed by Grim and Finke (2006) now cover the period from 2003 to 2008.

${ }^{3}$ Democracy can be conceptualized in a variety of manners. Here a minimalist (i.e., electoral) conception is adopted. This is in accordance with the theoretical argument, with its focus on the scope of political competition.

${ }^{4}$ I use Sangha (upper case) to refer to the ecclesiastic hierarchy, and sangha (lower case) to refer to the wider monkhood.

${ }^{5}$ Discussion of government budget data (here and subsequently) is based on author's calculations using information on government budgets as published in Bureau of the Budget, Ngoppraman Doi Sangkhep [Thailand's Budget in Brief] (Bangkok: Prime Minister's Office) or in Ratchakitchanubeksa, available online at http://www.mratchakitcha.soc.go.th.

${ }^{6}$ The data used here referes to budget appropriations. Government spending and expenditure are used interchangeably to refer to budget appropriations. The Thai fiscal year runs from October 1 
to September 30. The budget is generally passed into law several months prior to the start of the fiscal year. To avoid confusion between calendar and fiscal years, all yearly references are for the calendar year unless it is indicated that they are for the fiscal year.

${ }^{7}$ The distinction between autocracy and democracy hinges on whether the executive came to power through fair and competitive elections. Given the theoretical concern with political competition it will be useful also to make a distinction between two different types of autocratic regimes: those without and those with popularly elected legislatures.

${ }^{8}$ The data for the different prime ministers only refers to the budgets they were responsible for passing. Prime ministers often administer the budgets of their predecessors when they first take office. While the period from 1973 to 1976 is often referred to as a democratic interlude, only one budget was passed by a fully democratic government in this three-year period: that of Kukrit Pramoj.

${ }^{9}$ Interview with Chuan Leekpai, Bangkok, 19 September 2017.

${ }^{10}$ Many of these issues are discussed in the next section.

${ }^{11}$ It should be noted that religious orientation is not a salient part of the cleavage structures defining the Thai party system.

\section{References}

Arghiros, Daniel, Rural Transformation and Local Politics in a Central Thai District, $\mathrm{PhD}$ Dissertation, University of Hull, 1993.

Bangkok Post, "Budget Will Hurt the Poor, Says Opposition,” 30 June 1989.

Bueno de Mesquita, Bruce, Alastair Smith, Randolph M. Siverson, and James D. Morrow, The Logic of Political Survival (Cambridge: MIT Press, 2003).

Chaves, Mark, Peter J. Schraeder, and Mario Sprindys, "State Regulation of Religion and Muslim Religious Vitality in the Industrialized West," Journal of Politics 56 (November 1994).

Christensen, Scott, David Dollar, Ammar Siamwalla, and Pakorn Vichyanond, Thailand - The Lessons of East Asia: The Institutional and Political Underpinnings of Growth (Washington DC: World Bank, 1993). 
Driessen, Michael T., Religion and Democratization: Framing Religious and Political Identities in Muslim and Catholic Societies (Oxford: Oxford University Press, 2014).

Fox, Jonathan, "World Separation of Religion and State into the $21^{\text {st }}$ Century," Comparative Political Studies 39 (June 2006), 537-69.

Fox, Jonathan, Political Secularism, Religion, and the State: a Time Series Analysis of Worldwide Data (New York: Cambridge University Press, 2015).

Gabaude, Louis, "La Triple Crise Du Bouddhisme en Thaillande (1990-1996)," Bulletin De L'Ecole Française D'Extrême-Orient 83 (1996), p. 247-253.

Geddes, Barbara, Joseph Wright, and Erika Frantz, “Autocratic Breakdown and Regime Transitions: A New Data Set" Perspectives on Politics 12 (June 2014), 313-31.

Gill, Anthony, "The Political Origins of Religious Liberty: a Theoretical Outline," Interdisciplinary Journal of Research on Religion 1 (2005), 1-35;

Gill, Anthony, The Political Origins of Religious Liberty (Cambridge: Cambridge University Press, 2007).

Gray, Christine E., Thailand: The Soteriological State in the 1970s, PhD Dissertation, University of Chicago, 1986.

Grim, Brian J., and Roger Finke, "International Religion Indexes: Government Regulation, Government Favoritism, and Social Regulation of Religion," Interdisciplinary Journal of Research on Religion 2 (2006), 1-40.

Jackson, Peter A., Buddhism, Legitimation, and Conflict: the Political Functions of Urban Thai Buddhism (Singapore: Institute of Southeast Asian Studies, 1989).

Jackson, Peter A., "Withering centre, flourishing margins: Buddhism's changing political roles," in Kevin Hewison, ed., Political change in Thailand: Democracy and Participation (London: Routledge, 1997).

Katewadee Kulabkaew, "In Defense of Buddhism: Thai Sangha's Social Movement in the Twenty-First Century,” PhD Dissertation, Waseda University, 2013.

Kinnvall, Catarina, "Globalization and Religious Nationalism: Self, Identity, and the Search for Ontological Security," Political Psychology 25 (October 2004), 741-67.

Keyes, Charles F., "Buddhist Politics and their Revolutionary Origins in Thailand," International Political Science Review 10 (April 1989). 
Kuru, Ahmet T., "Passive and Assertive Secularism: Historical Conditions, Ideological Struggles, and State Policies Toward Religion," World Politics 59 (July 2007), 568-94.

Kusa, Julian, Crisis discourse, response, and structural contradictions in Thai Buddhism, 19902003. PhD Dissertation, Australian National University, 2007.

Larsson, Tomas, “Keeping Monks in Their Place?” Asian Journal of Law and Society 3 (2016). Levitsky, Steven, and Lucan A. Way, Competitive Authoritarianism: Hybrid Regimes after the Cold War (New York: Cambridge University Press, 2010).

McCargo, Duncan, Chamlong Srimuang and the New Thai Politics (London: Hurst, 1997).

McCargo, Duncan, Tearing Apart the Land: Islam and Legitimacy in Southern Thailand (Ithaca: Cornell University Press, 2008).

McCargo, Duncan, "The Changing Politics of Thailand's Buddhist Order," Critical Asian Studies 44 (2012), 627-42.

Mezey, Michael L., "The 1971 Coup in Thailand: Understanding Why the Legislature Fails," Asian Survey 13 (March 1973).

Mohamad, Maznah, "The Ascendance of Bureaucratic Islam and the Secularization of the Sharia in Malaysia" Pacific Affairs 83 (September 2010), 505-24.

Neher, Clark D., "Thailand: Toward Fundamental Change," Asian Survey 11 (February 1971).

Phillips, Herbert P., "The Election Ritual in a Thai Village," Journal of Social Issues 14 (October 1958), p. 49.

Religious Affairs Department, Raingan kansatsana pracham pi 2513 [Annual report of religion activities 1970].

Selway, Joel Sawat, "Electoral Reform and Public Policy Outcomes in Thailand: The Politics of the 30-Baht Health Scheme," World Politics 63 (January 2011).

Sezgin, Yüksel, and Mirjam Künkler, "Regulation of 'Religion' and the 'Religious': The Politics of Judicialization and Bureaucratization in India and Indonesia," Comparative Studies in Society and History 56 (2014), 448-78.

Slater, Dan, "Revolutions, Crackdowns, and Quiescence: Communal Elites and Democratic Mobilization in Southeast Asia," American Journal of Sociology 115 (July 2009), 203-54.

Somboon Suksamran, Political Buddhism in Southeast Asia: the Role of Sangha in the Modernization of Thailand. (London: C. Hurst \& Company, 1977). 
Stepan, Alfred, "The Multiple Secularisms of Modern Democratic and Non-Democratic Regimes," in Craig Calhoun, Mark Jurgensmeyer, and Jonathan Vanantwerpen, eds., Rethinking Secularism (Oxford: Oxford University Press, 2011), 114-144.

Suwanna Satha-anand, "Buddhist Pluralism and Religious Tolerance in Democratizing Thailand," in Philip Cam, ed., Philosophy, Democracy, and Education (Seoul: Korean National Commission for UNESCO, 2003), 193-213.

Taylor, Jim, "Buddhist Revitalization, Modernization, and Social Change in Contemporary Thailand." Sojourn: Journal of Social Issues in Southeast Asia 8 (February 1993).

Thak Chaloemtiarana, Thailand: The Politics of Despotic Paternalism (Ithaca: Southeast Asia Program Publications, 2007).

Traunmüller, Richard, and Markus Freitag, "State Support of Religion: Making or Breaking Faith-Based Social Capital?” Comparative Political Studies 43 (April 2011), 253-69.

\section{Author biography}

Tomas Larsson is Senior Lecturer in the Department of Politics and International Studies and Fellow of St John's College at the University of Cambridge. He is the author of Land and Loyalty: Security and the Development of Property Rights in Thailand (2012). 